\title{
Flight muscles degeneration, oogenesis and fat body in Lasius niger and Formica rufa queens (Hymenoptera: Formicidae)
}

\section{Аегенерация крыловой мускулатуры, оогенез и жировое тело у самок Lasius niger и Formica rufa (Hymenoptera: Formicidae)}

\author{
Elena B. Fedoseeva ${ }^{1}$, Natalya A. Grevtsova ${ }^{2}$ \\ Е.Б. Федосеева, Н.А. Гревцова
}

\footnotetext{
${ }^{1}$ Zoological Museum of Lomonosov Moscow State University, Bolshaya Nikitskaya Street 2, Moscow, 125009 Russia. E-mail: elfedoseeva0255@yandex.ru

2 Dept. of Entomology, Faculty of Biology, MSU, 1-12 Leninskie Gory , GSP-1, Moscow, 119991 Russia. E-mail: grev-natik@yandex.ru

1 Зоологический музей МГУ им. М.В. Ломоносова, Большая Никитская ул., 2, Москва, 125009 Россия.

2 Каф.энтомологии, Биологический ф-т, МГУ им. М.В. Ломоносова, Ленинские горы, 1, стр. 12, ГСП-1, Москва, 119991 Россия.
}

KEY WORDS: comparative anatomical, colony founding, Formica rufa, indirect flight muscles, hystolysis, adipogenesis, ovary, egg.

КЛЮЧЕВЫЕ СЛОВА: сравнительно-анатомическое, основание семьи, крыловые мышцы непрямого действия, гистолиз, адипогенез, яичник, яйцо.

ABSTRACT. Queens of Lasius niger with their independent mode of colony founding have a much higher fat content than red wood ants queens, which create new colonies either via budding or through temporary social parasitism. After nest foundation, an $L$. niger queen will never leave it to forage. Therefore, until workers appear, vital activities of the queen require reserves that are within the extremely well-developed gaster fat body, and later, the degeneration of the flight muscles. This comparative anatomical research demonstrated that both alate and dealate young queens of red wood ants collected in nature have no such gaster reserves. During nuptial flight and a month after wings shedding the gaster of the ants remained compact and free of the massive fat body that is specific to $L$. niger queens. Ovarian development in young queen red wood ants is closely dependent on the degeneration of indirect flight muscles. The process of degeneration includes two distinguishable stages: progressive and active hystolysis of muscle fibers, and two stages of fiber sheaths adipogenesis. Ovarian growth in queen red wood ants takes place during the active hystolysis of muscles, but the oogenesis of the first eggs produced occurs during a long period of muscle fiber sheaths adipogenesis. Ant workers likely play a key role in providing provisions for the queen in the final stage of initial egg development. In contrast, in young $L$. niger queens, the first batch of eggs is formed much earlier, in the first days after wings shedding, when external manifestations of flight muscle hystolysis are absent, and the abdomen contains a fat body. It is assumed that, unlike L. niger, young red wood ant queens lay their first eggs after nuptial flight no earlier than following spring.

РЕЗЮМЕ. Самки Lasius niger, с их независимым способом основания семьи, по содержанию жира значительно превосходят самок рыжих лесных муравьев, семьи которых возникают либо путём почкования, либо в результате временного социального паразитизма. После закладки гнезда самка L. niger не покидает его для фуражировки, так что до выхода первых рабочих её жизнедеятельность обеспечивают запасы чрезвычайно развитого в брюшке жирового тела, а позднее - дегенерация крыловых мышц. Сравнительно-анатомическое исследование показало, что собранные в природе как крылатые, так и бескрылые молодые самки рыжих лесных муравьёв таких запасов в брюшке не имеют. Во время брачного лёта и спустя месяц после сбрасывания крыльев их брюшко остается компактным и свободно от массивного жирового тела, присущего L. niger. Развитие яичников у молодых самок рыжих лесных муравьёв тесно связано с дегенерацией крыловых мышц непрямого действия. Процесс дегенерации включает явственно отличающиеся стадии: прогрессивного и активного гистолиза мышечных волокон, а также две стадии адипогенеза волокон. Рост яичников у самок рыжих лесных муравьёв проходит на стадии активного гистолиза мышц, но оогенез первой порции яиц завершается в период адипогенеза оболочек мышечных волокон. Рабочие муравьи, по-видимому, играют решающую роль в обеспечении самки на заклю-

How to cite this article: Fedoseeva E.B., Grevtsova N.A. 2020. Flight muscles degeneration, oogenesis and fat body in Lasius niger and Formica rufa queens (Hymenoptera: Formicidae) // Russian Entomol. J. Vol.29. No.4. P.410-420. doi: 10.15298/rusentj.29.4.08 
чительном этапе развития первых яиц. Напротив, у молодых самок L. niger первая порция яиц формируется гораздо раньше, в первые дни после сбрасывания крыльев, когда ещё нет внешних проявлений гистолиза крыловых мышц, а брюшко заполнено жировым телом. Предполагается, что в отличие от $L$. niger, молодые самки рыжих лесных муравьёв способны отложить свои первые после брачного лёта яйца не ранее весны следующего года.

\section{Introduction}

In the temperate zone, the first young workers appear within Lasius niger (Linnaeus, 1758) nests in June, while the nuptial flight period lasts from early July to September. After insemination, queens shed their wings and immediately initiate nest founding [Zakharov, 2015]. Hatching of the first generation after wintering in Formica rufa (Linaeus, 1876) and $F$. polyctena Forster, 1850 ants occurs earlier, in May. Further, in addition to workers, viable colonies of $F$. rufa and $F$. polyctena produce sexual individuals. Nuptial flight in red wood ants takes place earlier than it does in L. niger, and its duration is shorter, occurring from early May to early June [Zakharov, 2015]. Young queens, after mating and wing shedding, have two options: to remain at the natal anthill or independently search for a new one, for which they employ colonies of Serviformica ants. In the former case, the queen may become a member of a new colony via maternal anthill budding, and in the latter, she progresses with the support of the unrelated colony [Dlussky, 1967]. In either case, the queen requires the participation of ant workers. This type of colony founding is called 'dependent'. In contrast, independent colony founding typically occurs in L. niger and many Formicidae species [Hölldobler, Wilson, 1977; Keller, Passera, 1989].

Lasius niger and red wood ant queens also differ physiologically at hatching. It was determined that the fat content in dry weight of queen $L$. niger after emerging from the pupa is $22 \pm 2 \%$. In contrast, the fat content in dry weight of red wood ant species was determined to be $8 \pm 2-12 \pm 1 \%$ [Keller, Passera, 1989]. Even more significant differences in fat content were observed between queens at the time of mating in which L. niger and red wood ants were reported to have a fat content of $51 \pm 1 \%$ and $10 \pm 2-13 \pm 2 \%$, respectively [ibid.]. However, the glycogen content in the dry weight of alates was greater in queens of red wood ant species (5.85-8.27\%) than in those of L. niger (4.5\%) [Passera, Keller, 1990].

The fat body of insects is both a storage and source of lipids, proteins and carbohydrates, which serve as precursors for the metabolism of various substances. In particular, the fat body enables the synthesis of oocyte proteins, such as vitellogenins [Keeley, 1985; Kunkel, Nordin, 1985; Roma et al., 2010]. In insects, the fat body is considered the principal organ that facilitates intermediate metabolism. It is formed by cells of mesodermal and ectodermal origin [Chapman, 1998; Roma et al., 2010]. The former are made up of trophocytes and their derivatives (adipocytes, uratocytes, etc.), and the latter are made up of enocytes [Chapman, 1998]. The bulk of the fat body consists of adipocytes. Studies of Attini ants have demonstrated the presence of lipid vesicles and protein granules in fat body cells both in queens and workers, as well as the activity of cellular structures required for the production of these substances [Roma et al., 2010].

The fat body contains numerous lobes and clusters of cells. Its periphery is comprised of a parietal layer adjacent to the body wall, and a layer that surrounds internal organs called the perivisceral layer [Schwanwitsch, 1949]. The fat body is most conspicuous in the abdomen, but some portions of the organ extend into the thorax and head [Chapman, 1998]. In imagoes, perhaps this is the most dynamic organ since its content and size changes throughout the life of an insect. Differences in the wintering weight and summer ant workers have been demonstrated in individuals of $F$. polyctena, due to changes in the volume of fat body reserves [Kneitz, 1967]. In ant queens, the most significant fat body reorganization that occurs is associated with flight muscle degeneration after wings shedding.

In the early 19th century Charles Janet studied microscopic changes in the flight muscles of ant queens after the nuptial flight [Janet, 1907]. He identified two interrelated processes that occurred in the musculature: a) hystolysis, which results in degeneration so that only sheaths of muscle fibers (sarcolemma) and tracheal structures that serve muscle remain; and b) adipogenesis, in which hemolymph cells penetrate the gradually emptying sarcolemma of muscle fibers, where they turn into new adipocytes. The nutrients released during hystolysis support the growth of adipocytes, which synthesise both protein granules and lipid vesicles. Hystolysis starts prior to adipogenesis, which follows and develops as nutrients accumulate within fiber sheaths and the surrounding hemolymph. Janet remarked that the rates of hystolysis are not the same in the fibers of different muscles. In particular, the indirect flight muscles are the first to undergo hystolysis, while direct muscles are last. Both processes have been described and illustrated in detail using specimens that differed in periods after nuptial flight (from several days to one year and 10 months old).

According to Janet [1907], in the first days after the wings shedding, the flight muscles of dealate queens display no external signs of degeneration despite the fact that necrosis has been initiated. The external manifestation of progressive hystolysis involves the narrowing of the muscle fibers and the formation of gaps between fibers, which is caused by the detachment of the myofibrillar mass from sheaths and the exit of hystolysis fluid (18-24 days post wings shedding). During active hystolysis, hemolymph containing decomposition products looks like a mushy mass. In addition, adipocytes growing in the hemolymph outside fiber sheaths are visible under the microscope (26-32 days post wings shedding). The filling of the fiber sheaths with adipocytes, their growth, as well as their adhesion to the outside of fiber sheaths is visible approximately $1.5-2$ months post wings shed- 
ding. After 10 months, columns of adipocytes that completely replaced previous contents of fiber sheaths are clearly visible. The sheaths of fibers are held together with tracheas and their branches that were preserved during hystolysis. Therefore, throughout the course of adipogenesis, formations appear that outwardly resemble degenerated muscles.

A close relationship between the degeneration of the flight muscles, the fat body and oogenesis in ant queens has been noted by many authors [Janet, 1907; Dlussky, 1967; Brian, 1983]. A positive correlation between ovarian development and fat body size in young ant workers has been reported [Kneitz, 1967; 1969]. Other reports investigated the ratio of queens collected from anthills in spring with different levels of ovary or wing muscles development [Chautems et al., 1988]. However, a joint comparative research analysis of the fat body, ovaries and flight muscles of ant queens in species that utilize different modes of colony founding has not previously been carried out.

\section{Materials and methods}

\section{Collection}

Material for comparative anatomical research was collected within Moscow and the surrounding Moscow region. Each specimen was placed in a separate tube containing $70 \%$ ethanol immediately after capture. The dispersing dealate queens of $L$. niger were collected in the Druzhba park (Moscow) during their mass appearance on the territory in July of 2011 (Table 1). The queens of red wood ants were collected in a mixed forest near the

Table. 1 The state of internal organs in dealate queens of L. niger, collected during dispersal after nuptial flight (collection date 27.07.2011).

Табл. 1 Состояние внутренних органов у бескрылых самок L. niger, собранных при расселении после брачного лёта 27 июля 2011.

\begin{tabular}{c|c|c|c|c|c|c|c}
\hline № & FB & ld & Sovl & Sm & इeg & cr & mg \\
\hline 1 & 3,5 & ++ & J-V & 0 & 8 & - & - \\
\hline 2 & 3,5 & ++ & J-V & 0 & 4 & - & + \\
\hline 3 & 4 & ++ & E2-V & 0 & 8 & - & + \\
\hline 4 & 4 & ++ & E3-V & 0 & 16 & - & - \\
\hline 5 & 4 & ++ & E3-V & 0 & 12 & - & + \\
\hline 6 & 4 & ++ & E2-V & 0 & 10 & - & + \\
\hline 7 & 4 & ++ & E2-V & 0 & 10 & - & + \\
\hline
\end{tabular}

ABBREVIATIONS: FB - fat body index, ld - abundance of lipid drops, cr - food in crop, $\mathrm{mg}$ - food in midgut, Sovl — ovariol stages, Sm - degradation stage of indirect flight muscles, $\Sigma$ eg total eggs in the ovaries, other - in the text.

ОБОЗНАЧЕНИЯ: FB - индекс жирового тела, ld - обилие жировых капель, cr - наличие пищи в зобе, mg - наличие пищи в средней кишке, Sovl - стадии овариол, Sm - стадия деградации мышц непрямого действия, $\Sigma$ eg - всего яиц в яичниках, прочее-в тексте
Zvenigorod Biological Station (ZBS, Moscow region). Several assessments that were performed since the 1970s have revealed that only two species from Formica rufa group, $F$. rufa and $F$. polyctena, inhabit the ZBS forest. Further, ants with phenotypes of both species have been found in many ZBS anthills, but the ratio of phenotypes at the same anthill tend to vary from year to year (unpublished data). Now, these species are considered to be the closest phylogenetic relatives within Formica rufa species group with incomplete divergence [Goropashnaya et al., 2004]. In the present study, the queens of red wood ants from ZBS are referred to using the common name F. rufa.

After mating, young red wood ant queens may remain in their natal anthill or disperse in search of a new nest [Dlussky, 1967; Fortelius et al, 1993]. During nuptial flight, dealate queens of $F$. rufa may be found together with alates on the anthills. However, after the mating period, unlike L. niger, it is difficult to find single dispersal queens throughout the territory. Dealate queens that are transported by workers may be found on the anthill trails during colony emigration or budding. Therefore, the collection of $F$. rufa took place from spring to early autumn in 2017-2019 (Table 2); the period of nuptial flight was the same (early May-early June) throughout all years assessed. Alate queens of $F$. rufa were also collected for comparison. Accordingly, Table 2 includes data describing characteristics of the internal organs of specimens, the type of queen identified (alate or dealate), and also whether the specimen was single or belonged to an anthill.

\section{Specimen dissection and photography}

Dissections were carried out using an insulin syringe and tools for ophthalmic microsurgery (spring scissors, blade holder and forceps). Each specimen preserved in $70 \%$ ethanol was moved to a dry Petri dish $(\mathrm{d}=40 \mathrm{~mm})$, where a large water drop was applied to completely cover the gaster. The dissection of wet specimens was executed under an Olympus SZX10 stereomicroscope. The gaster membrane between the fourth and fifth tergites was pierced with insulin needle, and scissors were inserted into the puncture. All gaster tergites were removed via circular incision. The abundance of lipid drops was noted during the gaster autopsy. Further, the presence of food in the crop and midgut was determined with incisions. Dissection of the mesosoma was performed using a similar technique: part of mesosoma sclerite was removed from its lateral side with scissors. After the specimen was cleared with water, the mesosoma as well the gaster were separately photographed. Then, the upper layer of the gaster fat body was removed and the presence of perivisceral fat on internal organs was assessed. The ovaries were cleared mechanically of fat, if necessary, before the re-photographing of the gaster. Photographs of wet specimens were taken using an Olympus SZX10 stereomicroscope with a DeltaPix Invenio-8DII digital camera, and images were Z-stacked using Helicon Focus 6.7.1. All images were edited in Adobe Photoshop CS6. 


\section{Assessment of internal organs}

In order to compare the state of three organ systems in different species, it was necessary to create gradation scale for each system that could be used throughout autopsies.

Gaster fat body, crop and midgut. Prior studies that investigated the state of the ovaries and fat body in ant workers used qualitative gaster fat body size gradation, as follows [Fedoseeva, 2018]: 0, most organs are visible and a thin translucent layer of adipocytes is present on gaster sclerites; 1, a thickened white layer of the fat body on the sclerites is observable; 2 , internal organs are partly covered with fragments of fat body; 3 , the fat body fills the gaster, but gaps between organs are present; 4, fat-free lacunae are absent. The gradation scale describes the mutual growth of the parietal and visceral layers of fat body. For example, if only parietal layer present, then fat body index values are $0-1$. If the perivisceral layer is also visible, then a 2 value is given, and if both layers are fused partially or merged completely, then 3 or 4 is given, respectively. The presence or absence of food in the crop and midgut was also noted.

Ovaries. There has been no prior description of ant queen-specific ovarian stages. The state of queen's ovaries (Fig. 1) was determined based on the classification system of D. Otto, which was used to describe Formica s. str. ant workers [Otto, 1958]. The system is comprised of stages that reflect stereomicroscopically visible changes at low magnification, as follows (Fig 2): the initial stage $(\mathrm{J})$, is characterized by the presence of white, thin, ovarioles that evenly-expand toward the oviduct; the initial growth stage (E1) occurs when the first cells are identified in the lower part of ovarioles; the middle growth stage (E2) occurs when differences between oocytes and trophocytes (nutrient cells) become visible, and the length of ovarioles is increased; the growth stage before completion (E3) is characterised by the terminal oocyte size significantly exceeding those of primary oocytes; and the final growth stage (V) occurs when the terminal oocyte reaches its maximum size. Subsequent stages including resorption (R1, R2) and degeneration (D) are common for workers, but were absent in queens evaluated in this study. The earliest and latest stages were noted if oogenesis within different ovarioles was asynchronous.

Indirect flight muscles. Two pairs of thoracic insect muscles are named indirect or asynchronous flight muscles: the dorsal longitudinal and dorso-ventral pairs (in Hymenoptera these are prophragmo-mesophragmal and first mesopleuro-mesonotal muscles, respectively). Based on Janet's description of muscle degeneration [Janet, 1907], we have created a scale suitable to characterizing the state of indirect flight muscles upon the autopsy of specimen. It includes several qualitatively different stages, as follows: 0 , the absence of external signs of necrosis; Hi1, progressive hystolysis; Hi2, ac-

Table 2. Characteristics of organs of alate and dealate queens of $F$. rufa collected during and after nuptial flight Табл.2 Состояние внутренних органов у крылатых и бескрылых самок $F$. rufa, собранных во время и после

\begin{tabular}{|c|c|c|c|c|c|c|c|c|c|c|}
\hline $\begin{array}{c}\text { collection } \\
\text { date }\end{array}$ & № & $\mathrm{A} / \mathrm{D}$ & $\mathrm{s} / \mathrm{f}$ & FB & ld & Sovl & $\mathrm{Sm}$ & $\sum$ eg & $\mathrm{cr}$ & $\mathrm{mg}$ \\
\hline \multirow{3}{*}{30.04 .2017} & 1 & A & $\mathrm{f}$ & 1,5 & - & $\mathbf{J}$ & 0 & 0 & + & + \\
\hline & 2 & $\mathrm{D}$ & $\mathrm{f}$ & 1,5 & + & $\mathbf{J}$ & 0 & 0 & - & + \\
\hline & 3 & $\mathrm{~A}$ & $\mathrm{f}$ & 1,5 & - & $\mathrm{J}$ & 0 & 0 & - & + \\
\hline \multirow{2}{*}{14.05 .2017} & 4 & $\mathrm{D}$ & $\mathrm{f}$ & 2 & - & V & Adl & 20 & - & + \\
\hline & 5 & $\mathrm{D}$ & $\mathrm{f}$ & 1 & - & $\mathrm{V}$ & Adl & 24 & - & + \\
\hline \multirow{6}{*}{18.06 .2017} & 6 & $\mathrm{D}$ & $\mathrm{s}$ & 1 & - & $\mathrm{E} 1$ & 0 & 0 & - & + \\
\hline & 7 & A & $\mathrm{f}$ & 2 & - & $\mathbf{J}$ & 0 & 0 & - & + \\
\hline & 8 & $\mathrm{~A}$ & $\mathrm{f}$ & 1,5 & + & $\mathrm{J}$ & 0 & 0 & + & + \\
\hline & 9 & $\mathrm{D}$ & $\mathrm{s}$ & 1,5 & + & $\mathbf{J}$ & 0 & 0 & + & + \\
\hline & 10 & A & $\mathrm{f}$ & 1 & - & $\mathbf{J}$ & 0 & 0 & - & - \\
\hline & 11 & A & $\mathrm{f}$ & 2 & - & $\mathrm{J}$ & 0 & 0 & - & + \\
\hline \multirow{2}{*}{20.06 .2019} & 12 & A & s & 2 & - & $\mathrm{J}$ & 0 & 0 & - & + \\
\hline & 13 & $\mathrm{D}$ & $\mathrm{f}$ & 2,5 & + & $\mathrm{J}-\mathrm{E} 1$ & Hil & 0 & - & + \\
\hline 21.06 .2017 & 14 & $\mathrm{D}$ & $\mathrm{f}$ & 2 & - & $\mathrm{V}$ & $\mathrm{Ad} 2$ & 15 & - & + \\
\hline 01.09 .2018 & 15 & $\mathrm{D}$ & $\mathrm{f}$ & 2,5 & ++ & E2-E3 & $\mathrm{Hi} 2$ & 0 & - & - \\
\hline
\end{tabular}


tive hystolysis; Ad1, progressive adipogenesis; and Ad2, the completion of adipogenesis (Fig. 3).

ABBREVIATIONS used in Figs 1-12: AC - columns of adipocytes; cr — crop; Dg — Dufour's gland; dlm - dorsal longitudinal muscle; dvm - dorsoventral muscle; e - egg; Fb - gaster fat body; Fe follicle epithelium; hg — hindgut; ld — lipid drops; lod lateral oviduct; $\mathbf{m g}$ - midgut; mod — median oviduct; op - primary oocytes; ot — terminal oocyte; Ov ovary; ovl — ovariole; Pg — poison gland; sp spermatheca; tr — trophocytes; tf — terminal filament

In general, terminology is in accordance with Chapman [1998] but also The Hymenoptera Glossary represented at the site of the Hymenoptera Anatomy Ontology project [Yoder et al., 2010]. The Russian translation partly follows Schwanwitsch [1949].

\section{Results}

Dealate queens of Lasius niger Table 1, Figs 4-6.

The fat body index of all queens was high: $3.5-4$. Fat tended to cover internal organs of the gaster so tightly that additional cleaning was required to determine their state. In all cases, an abundance of hydrophobic droplets was recorded, indicating a high fat content. Indirect flight muscles in all queens had no external signs of degeneration. The crop was empty in all individuals, and two queens also had empty midguts. All queens possessed 416 mature eggs, but oogenesis in ovarioles of their ovaries displayed a low degree of synchronization.

\section{Alate and dealate queens of Formica rufa Table 2, Figs 7-12.}

In general, the state of the internal organs of alate queens was almost identical (Fig. 7). The fat body index of the queens was low (1-2). Therefore, after the removal of tergites, all internal organs in gaster were visible. Only one specimen that possessed lipid drops upon autopsy (\#8 in Table 2). Indirect flight muscles showed no signs of degeneration, and the ovarioles of all alate queen ovaries were thin and white, corresponding to the J-stage of development. Just one queen had both an empty crop and a midgut (\#10 in Table 2), while the others had food in at least the midgut.

In contrast to alates, the state of the internal organs of dealate queens was heterogeneous (Figs 8-12). Fat
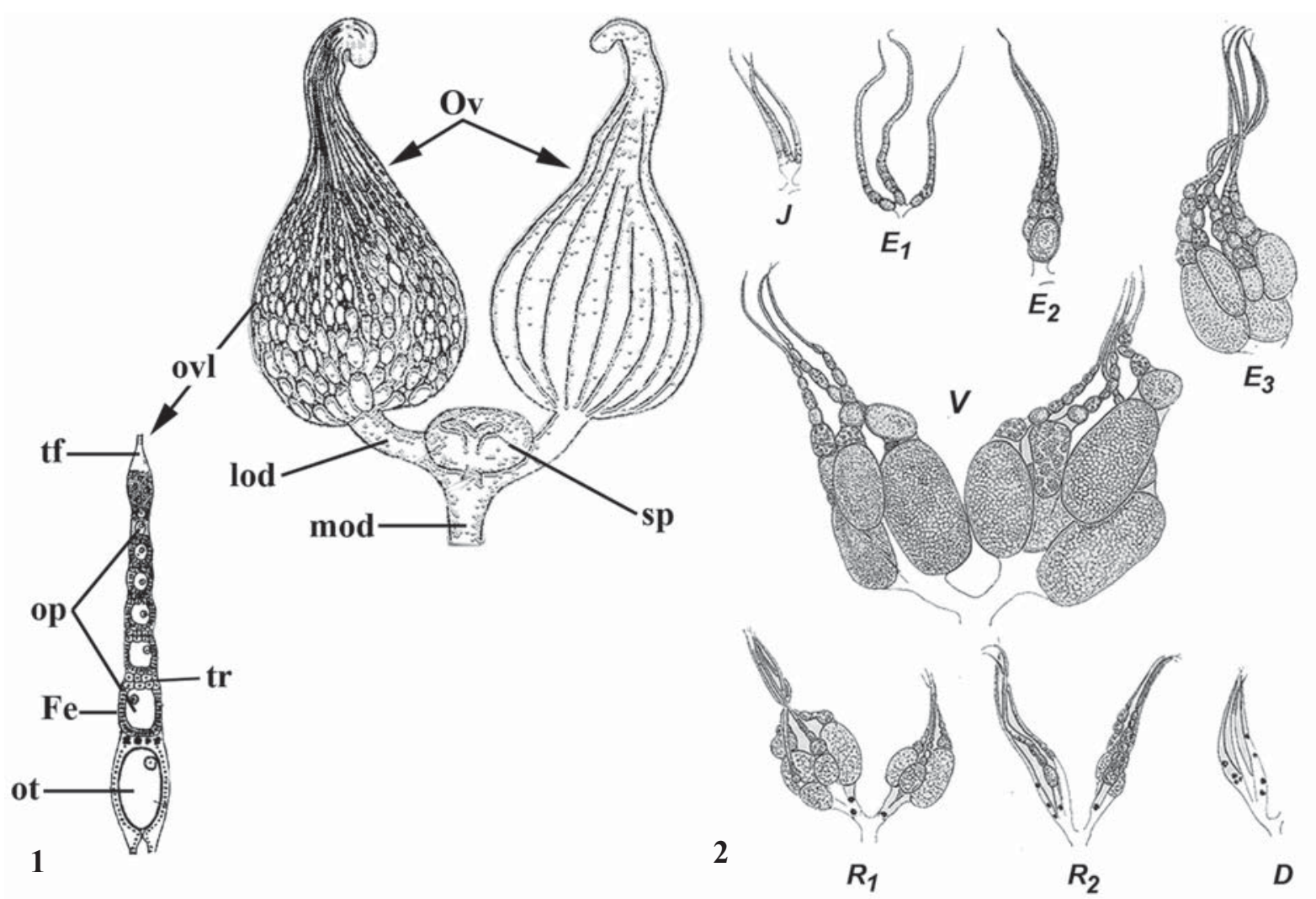

Figs 1-2. Reproductive systems in queen and workers of red wood ants: 1 - polytrophic ovariole, ovaries and oviducts in queen [partly after Schwanwitsch, 1949 and Otto, 1962]; 2 - stages of ovarian development in workers of $F$. rufa [after Otto, 1958]; $\boldsymbol{J}$ - initial stage of ovarie, $\boldsymbol{E} \mathbf{1}-\boldsymbol{E} \mathbf{3}$ and $\boldsymbol{V}$ - growth stages, $\boldsymbol{R} \mathbf{1}, \boldsymbol{R} \mathbf{2}$ - stages of resorption, $\boldsymbol{D}$ - stage of degeneration; other - in the text.

Рис. 1-2. Половая система самки и рабочих у рыжих лесных муравьёв: 1 - политрофическая яйцевая трубочка, яичники и половые пути самки [частично по Schwanwitsch, 1949 и Otto, 1962]; 2 - стадии развития яичников у рабочих $F$. rufa [по Оtto, 1958]; $\boldsymbol{J}$ - начальная стадия яичника, $\boldsymbol{E} \boldsymbol{1}-\boldsymbol{E} 3$ и $\boldsymbol{V}$ - стадии роста яичников, $\boldsymbol{R} \boldsymbol{1}, \boldsymbol{R} \boldsymbol{2}$ - стадии резобциии, $\boldsymbol{D}$ - стадии дегенерации; прочее - в тексте 
body index values varied between 1 and 2.5 in dealate queens. Like alates, values were lower than those of
L. niger. Moreover, unlike L. niger, the fat body was not adjacent to internal organs, and even queens with an

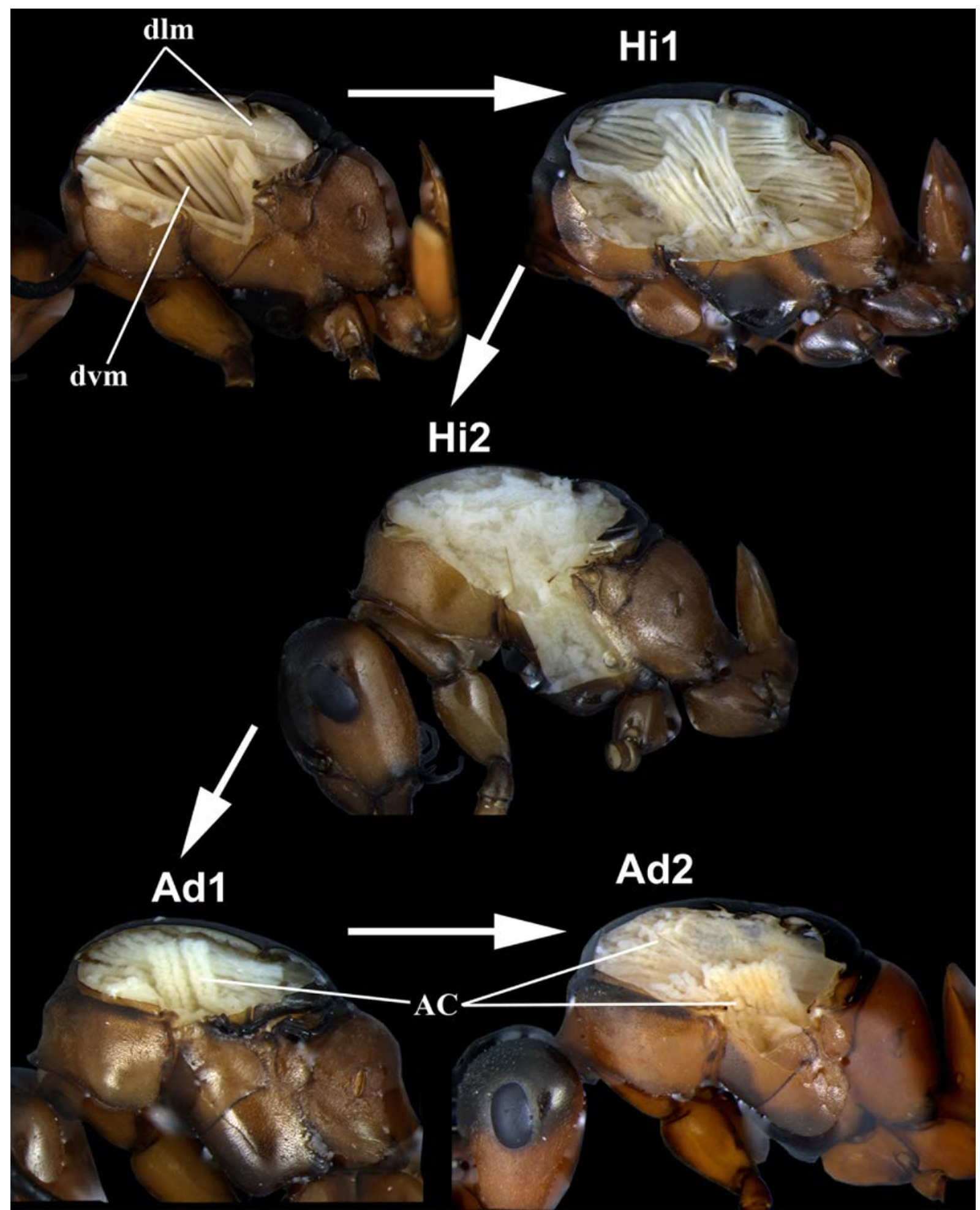

Fig. 3. Stages of indirect flight muscles degeneration in Formica rufa queens. Lateral view of a dissected mesosoma. Arrows indicate transitions from stages without external signs of necrosis (0) to stages in which hystolysis of muscle fibers occur (Hi1, Hi2) and their replacement by columns of adipocytes (Ad1, Ad2); other abbreviations - in the text.

Рис. 3. Стадии дегенерации крыловых мышц непрямого действия у самок $F$. rufa. Вскрытая мезосома, сбоку. Стрелками показаны переходы от стадии без проявлений некроза (0) до гистолиза мышечных волокон (Hi1, Hi2) и их замещения колонками адипоцитов (Ad1, Ad2); остальные обозначения - в тексте. 

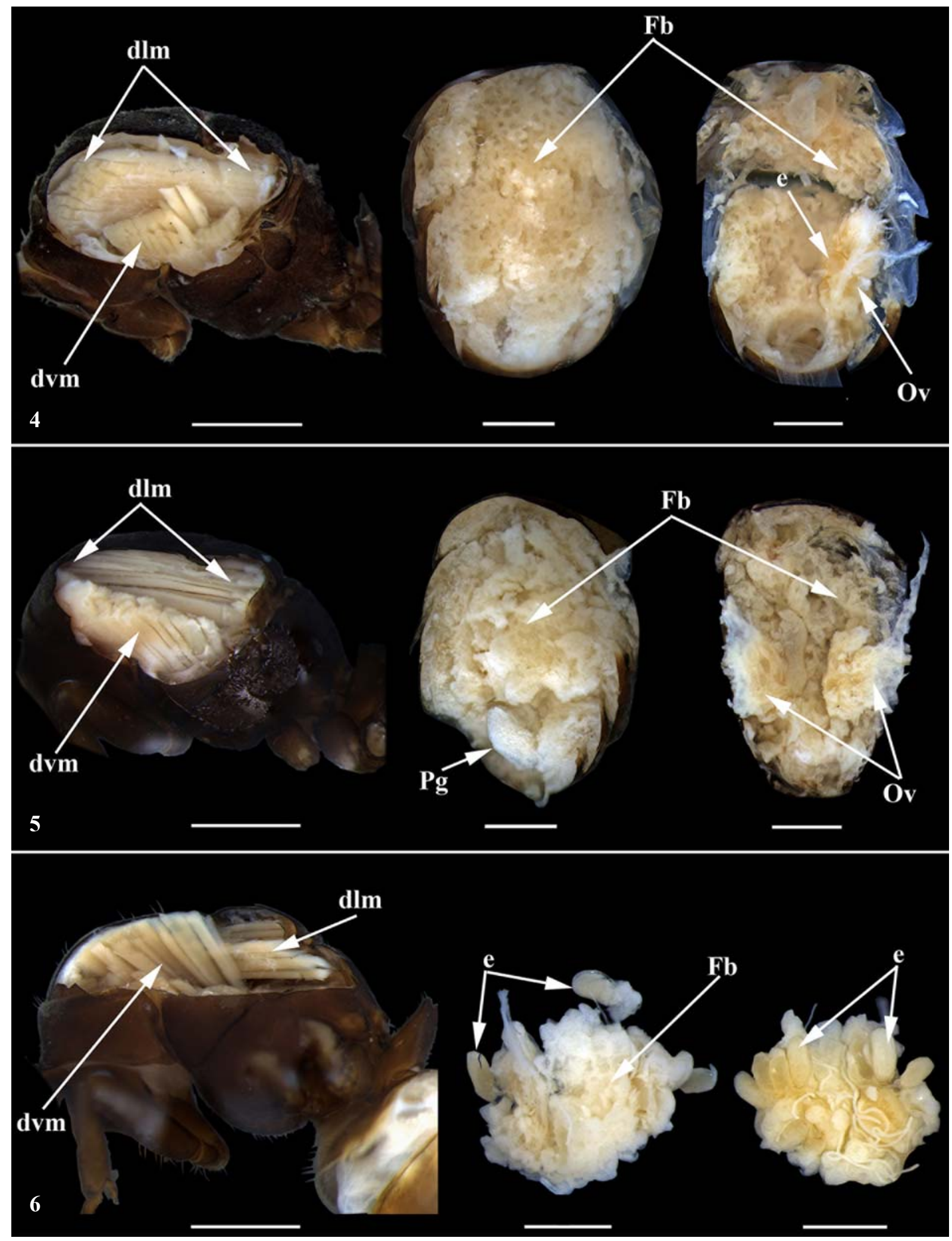

Figs 4-6. Indirect flight muscles, gaster fat body and ovaries in three young dealate queens of $L$. niger: 4-5 - from left to right, a dissected mesosoma from a lateral view, a dorsal view of gaster without tergites, gaster without part of fat body; 6 - from left to right, a dissected mesosoma from a lateral view, ovaries from dorsal and ventral view; abbreviation in the text. Scales: $1 \mathrm{~mm}$.

Рис. 4-6. Крыловые мышцы непрямого действия, жировое тело брюшка и яичники трёх молодых бескрылых самок L. niger: 45 - слева-направо, вскрытая мезосома, сбоку; вид на брюшко без тергитов, сверху; то же - удалена часть жирового тела; 6 - слеванаправо, вскрытая мезосома, сбоку; яичники - сверху и снизу; обозначения в тексте. Масштаб - 1 мм. 


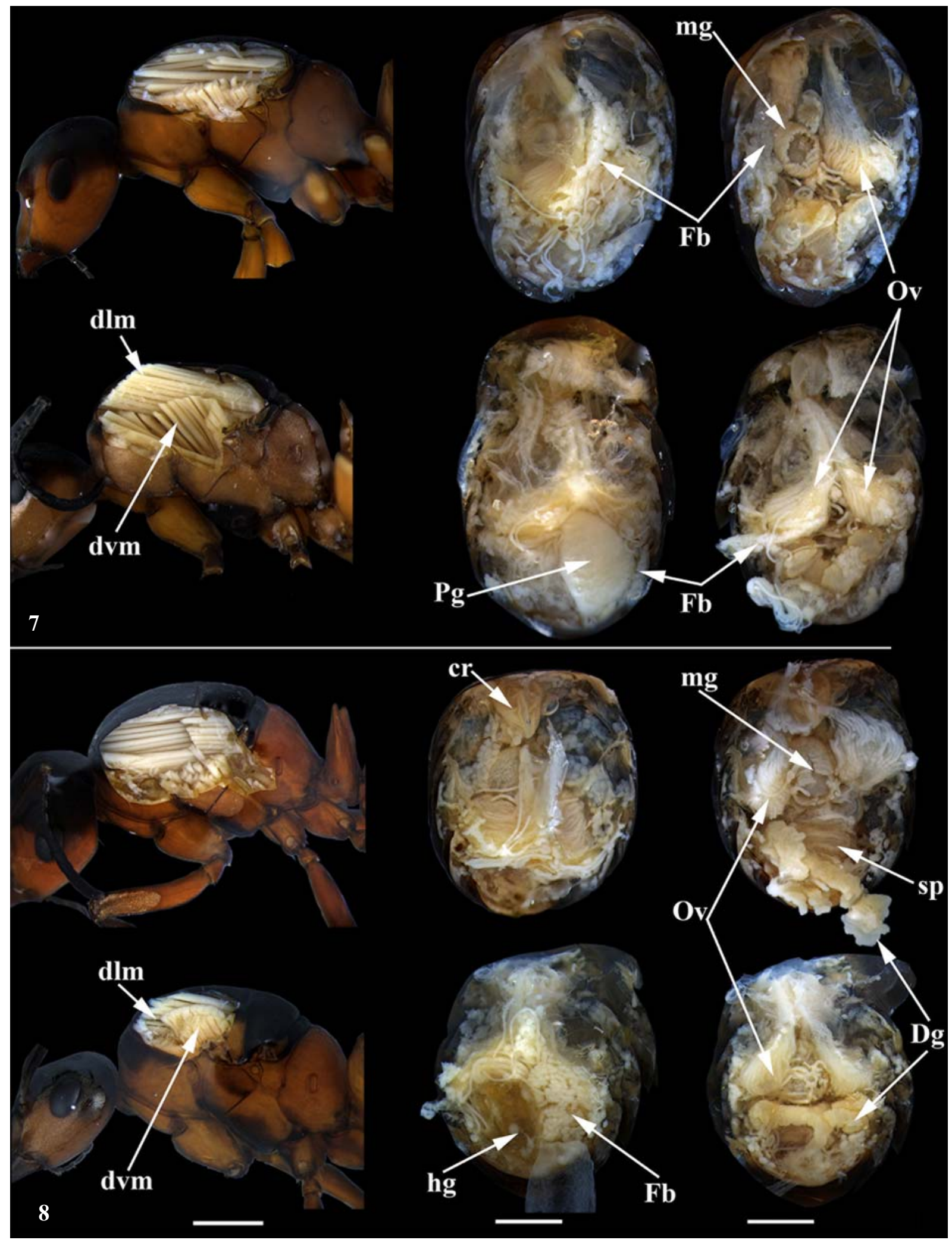

Figs 7-8. Indirect flight muscles, gaster fat body and ovaries in four young queens of F. rufa: 7 - from left to right: dissected mesosoma; gaster without tergites; gaster without part of the fat body for two alates; 8 - the same anatomy as described in 7 for two single dealate queens; abbreviations in the text. Scales: $1 \mathrm{~mm}$.

Рис. 7-8. Крыловые мышщы непрямого действия, жировое тело и яичники четырёх молодых самок $F$. $r u f a: ~ 7-$ слева-направо: вскрытая мезосома; брюшко без тергитов; брюшком с удаленной частью жирового тела у двух крылатых самок, 8 - то же, у двух бескрылых одиночных самок; обозначения в тексте. Масштаб - 1 мм. 
index of 2.5 had a perivisceral layer that was easily detachable. Ovarien state of dealate $F$. rufa queens varied between $\mathrm{J}$ and $\mathrm{V}$ stages, but stage differences between ovarioles of the same queen observed were less than in L. niger. In addition their variable degree of ovary development, dealate queens were heterogeneous in terms of their stage of indirect flight muscle degeneration. In three queens, external signs of muscle destruction were absent (Fig. 8). In two queens, hystolysis stages were observed (Hi1, Hi2; Figs 9-10, respectively), and in three queens, Ad1 and $\mathrm{Ad} 2$ adipogenesis stages were observed (Figs 11-12, respectively). The abundance of fat droplets upon gaster autopsy, typical for young $L$. niger queens, was noted in only one $F$. rufa queen, which was at the final stage of adipogenesis with eggs completely ready for laying.

The relationship between muscle degeneration and oogenesis become apparent in the active hystolysis stage (Hi2), when the hemolymph was saturated with products of muscle fiber breakdown and the "magma" of growing adipocytes. It is noteworthy that of the eight dealate queens of $F$. rufa assessed, only specimen (\#13, Table 2) had muscles in the stage of active hystolysis, and its crop and midgut were empty. The growth of oocytes and an overall increase in ovary size occurred precisely at the Hi2 stage (Fig. 10). In the earlier stages of degeneration, including Hi1, no difference in the size of the ovaries of alate and dealate queens was observed (Figs 8-9). The completion both the ovarian and oocyte growth (stage V) coincided with adipogenesis stages Ad1 and Ad2, at which point the perivisceral fat body of mesosoma was formed (Figs 11-12).

If we compare dates in which dealate queens were collected (Table 2), then the violation in the above mentioned stage sequence of muscle degeneration and oogenesis are notable. Indeed, queens \#2, 6 and 9 (April 30 and June 18) had no signs of muscle degeneration, and only one displayed an initial stage of ovarian growth. Queens \#4 and \#5 (May 14), however, had muscle fibers that were already in stages of adipogenesis, and their ovaries had completed growth. In turn, intermediate stages of oogenesis and muscle degeneration were observed in queens \#13 and \#15, which were captured at later dates (June 20 and September 1, respectively). This anomaly is possible in the following two cases: if variability in the rate of physiological rearrangement in young queens of the same age occurred, or if significant age differences between $F$. rufa queens included in the group of dealates occurred.

\section{Discussion}

The mode of colony founding used by different ant species is closely associated with physiological traits of their queens. As was observed in three subfamilies of Formicidae (Formicinae, Myrmicinae and Dolichoderinae), queens that create colonies independently have a greater fat content than queens of species that use a dependent mode of colony formation [Keller, Passera,
1989]. In dependent colony founders, new colonies are created either as a result of budding or a queen being adopted by a colony of another species. Differences occur within the same ant genus, e.g. Lasius or Formica. Thus, throughout the mating period, the fat content in dry weight of $L$. flavus queens that undergo independent colony foundation is almost 3 times higher than that of queens of L. fuliginosus, which have a dependent mode of colony formation. The fat content of queens in $F$. fusca, the host species of red wood ants, is two times higher than queens of the Formica rufa group. Further, the fat content of the latter was lowest among 24 species that were studied previously at $12-13 \%$ [Keller, Passera, 1989].

Our comparison of the fat body, ovaries and indirect flight muscles of young $L$. niger and $F$. rufa queens revealed additional differences. Regarding time of dispersal after nuptial flight, dealate queens of $L$. niger were characterised by their massive gaster fat body, in which both parietal and perivisceral layers were well developed. Both layers merged to form a cocoon around internal organs. Cells of the perivisceral layer tightly covered the ovaries, and up to 16 eggs were formed before the appearance of external signs of flight muscle degeneration, which, according to Janet, corresponded to initial days post wings shedding [Janet, 1907]. Since the first oviposition in L. niger occurs immediately after the nest foundation [Zakharov, 2011], it is clear that the oogenesis of the first eggs requires the gaster fat body, at least in part.

In contrast to L. niger, the gaster fat body of F. rufa queens is poorly developed in general. The thickness of its parietal layer is small, and its perivisceral layer, tends to be fragmented and does not tightly connect with the ovaries. Like L. niger, single dispersal dealate queens of $F$. rufa displayed no external signs of flight muscle necrosis, however, they did not contain eggs. The main stages of muscle degeneration, which were accompanied by ovarian development, were observed in dealate queens of $F$. rufa belonging to ant colonies. Oogenesis in young $F$. rufa queens is entirely associated with the degeneration of wing muscles and occurs in ovarioles more synchronously than it does in L. niger. Ovarian growth takes place at the stage of active hystolysis of muscle fibers, but the final stage of first eggs development coincides with adipogenesis, throughout which the perivisceral fat body of the mesosoma is formed.

In queens of $L$. niger, Janet observed columns of adipocytes that completely replaced indirect muscles 10 months after wings shedding [Janet, 1907]. At first glance, our results obtained for dealate queens of $F$. rufa collected in mid-May and June do not support such long-term physiological restructuring process. Indeed, individuals at the initial stages of oogenesis without signs of wing muscle necrosis were observed, as were queens with developed eggs that displayed adipogenesis of indirect muscles. This is possible according to two scenarios: 1) either that group contained specimens both current or previous seasons; 2) physiological changes in F. rufa queens may proceed after mating more 

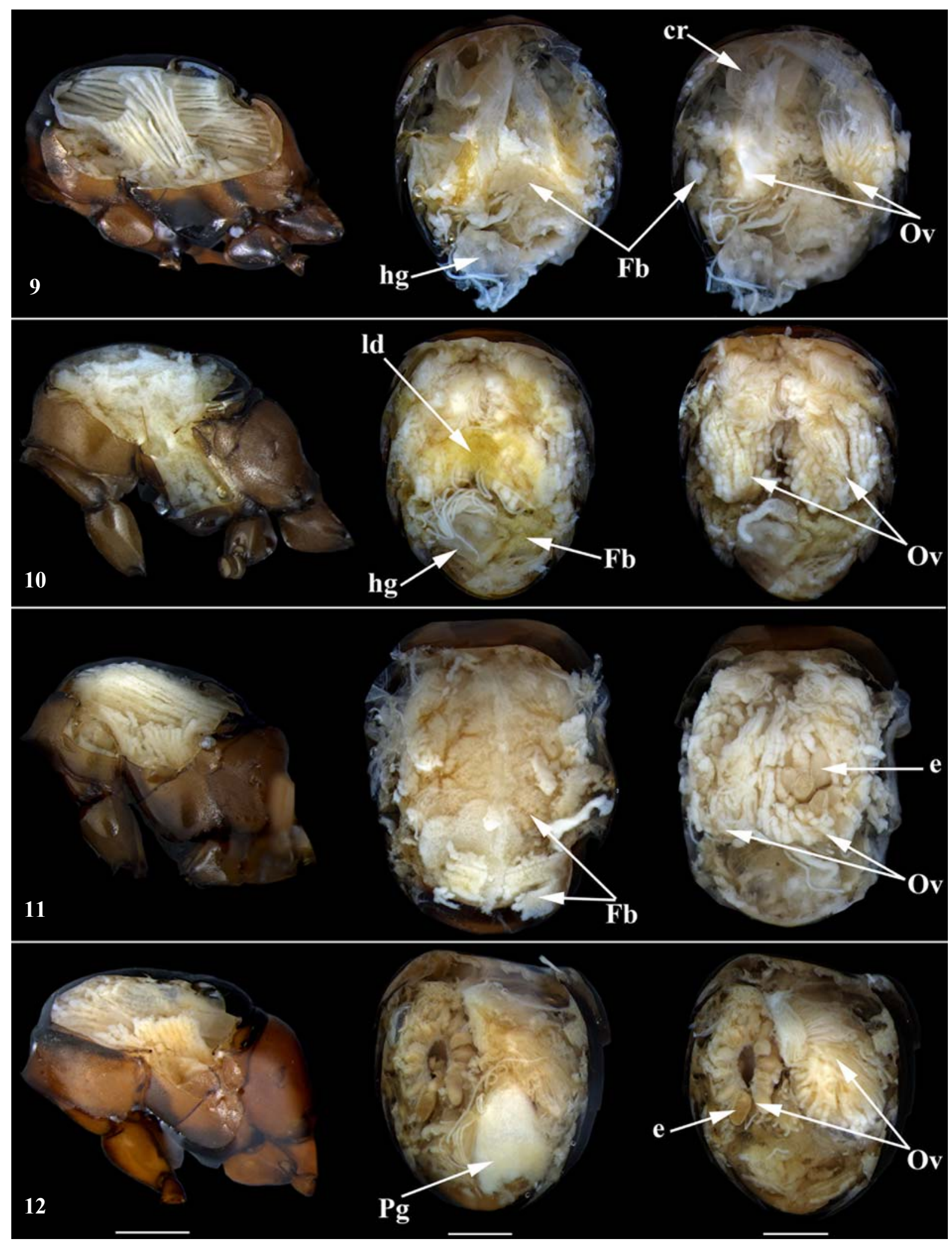

Figs 9-12. A dissected mesosoma, gaster fat body and ovaries in familial dealate queens of $F$. rufa at different stages of indirect flight muscle degeneration are shown: 9 - at the stage of progressive hystolysis, Hi1; 10 — at the stage of active hystolysis, Hi2; 11 - at the stage of progressive adipogenesis, Ad1; 12 - at the stage of completed adipogenesis, Ad2; abbreviations uin the text. Scale - $1 \mathrm{~mm}$

Рис. 9-12. Мезосома, жировое тело брюшка и яичники четырех семейных самок $F$. rufa на разных стадиях дегенерации крыловой мускулатуры: 9 - на стадии продвинутого гистолиза Нi1; 10 - на стадии активного гистолиза Нi2; 11 — на стадии продвинутого адипогенеза Ad1; 12 - завершенного адипогенеза Ad1. Масштаб - 1 мм 
rapidly than in L. niger. However, the fact that muscle hystolysis, as well as the intermediate ovarian stages, were observed in queens of $F$. rufa collected later (late June and early September) is in support of scenario 1. Reports of Swiss myrmecologists can serve as an additional confirmation of the long-term physiological restructuring reported to occur in red wood ant queens [Chautems et al., 1988]. The researchers studied queens that climbed out to the surface of the domes during the spring warming up of anthills, i.e. before the mating period of sex generation. However, the proportion of fertilized females varied between 5 nests from 70 to $97 \%$. At the same time, only in one of the anthills $23 \%$ of queens had eggs. All specimens of the rest nests were only at earlier stages of ovarian development. Therefore, it is likely that after nuptial flight, young queens of red wood ants lay their initial set of eggs no earlier than the following spring.

Acknowledgements. We would like to express our gratitude to the entire Zvenigorod biological station team at Moscow State University for their help conducting field research, and would like to personally thank the director of the station, Valery Gavrilov, as well as the station doctor Alexei Korzhavin for the constant support. Our special thanks go to the creators of the Gallica website from the electronic National library of France, which enabled us to read original versions of the classic work of Charles Janet. Preparation, dissection and imaging of samples were carried out with financial support of the Research project of the MSU Zoological Museum (AAAA-A16-116021660077-3).

Competing interests. The authors declare no competing interests.

\section{References}

Brian M.V. 1983. Social Insects: Ecology and Behavioural Biology // London and New York: Chapman \& Hall, $\mathrm{x}+377 \mathrm{pp}$

Chapman R.F. 1998. The insects: structure and function. $4^{\text {th }}$ ed Cambridge University Press. $770 \mathrm{pp}$.

Chautems D., Jaquet N., Cherix D. 1988. Etude du reveil printanier chez les fourmis des bois (groupe Formica rufa) dans le Jura vaudois (Suisse) // Actes Coll. Insectes Sociaux. Vol.4. P.185193.

Dlussky G.M. 1967. [Ants of the genus Formica (Hymenoptera, Formicidae, g. Formica)]. Moscow: Nauka. 236 pp. [In Russian]

Fedoseeva E.B. 2018. [The trophic eggs in ant workers, is it a rule or a deviation?] // Ants and Forest protection. Materials of the $15^{\text {th }}$ All-Russian Myrmecological Symposium, Yekaterinburg, 2018. Yekaterinburg: USFEU. P.54-59 [in Russian, with English summary].
Fortelius W., Rosengren R., Cherix D., Chautems D. 1993. Queen recruitment in a highly polygynous supercolony of Formica lugubris (Hymenoptera, Formicidae) // OICOS. Vol.67. No.2. P.193-200.

Goropashnaya A.V., Fedorov V.B., Pamilo P. 2004. Recent speciation in the Formica rufa group ants (Hymenoptera, Formicidae): inference from mitochondrial DNA phylogeny // Molecular Phylogenetics and Evolution. Vol.32. Iss.1. P.198-206.

Hölldobler B., Wilson E.O. 1977. The number of queens: an important trait in ant evolution // Naturwissenschaften. Vol.64. P.8-15.

Janet Ch. 1907. Anatomie du corselet et histolyse des vibrateurs, apres le vol nuptial, chez la reine de la fourmi (Lasius niger). Limoges. 149 pp.

Keeley L.L. 1985. Physiology and biochemistry of the fat body // G.A. Kerkut, L.I. Gilbert (Eds), Comprehensive Insect Physiology, Biochemistry and Pharmacology. Vol.3. Oxford: Pergamon Press. P.211-248.

Keller L., Passera L. 1989. Size and fat content of gynes in relation to the mode of colony founding in ants (Hymenoptera, Formicidae) // Oecologia. Vol.80. P.236-240.

Keller L., Passera L. 1990. Fecundity of ant queens in relation to their age and the mode of colony founding // Insectes Sociaux. Vol.37. No.2. P.116-130.

Kneitz G. 1967. Stichproben zur jahreszeitlichen Dynamik des Waldameisenstaates (Formica polyctena Forst.) // Progress in Soil Biology: proceedings of the Colloquium on Dynamics of Soil Communities, Braunschwig-Völkenrode, 5-10 September 1966. Braunschweig: Friedr. Vieweg \& Sohn GmbH. S.241-248.

Kneitz G. 1969. Jahreszeitliche Veränderungen der Ovariolenzustände in der Arbeiterinnenkaste des Waldameisenstaates von. Formica polyctena Foerst. (Hymenoptera, Formicidae) // Verhandlungen der Deutschen Zoologischen Gesellschaft. Bd.33. S.209-215.

Kunkel J.G., Nordin J.H. 1985. Yolk proteins // G.A. Kerkut, L.I. Gilbert (Eds), Comprehensive Insect Physiology, Biochemistry and Pharmacology. Vol.1. Oxford: Pergamon Press. P.83-111

Otto D. 1958. Über die Arbeitsteilung im Staate von Formica rufa rufo-pratensis minor Gössw. und ihre verhaltensphysiologischen Grundlagen: Ein Beitrag zur Biologie der Roten Waldameise. // Wissenschaftliche Abhandlungen Dtsch. Akad. Landwirtschaftswiss. zu Berlin. Nr.30. S.1-169.

Otto D. 1962. Die roten Waldameisen. Wittenberg Lutherstadt: A. Ziemsen Verlag. $152 \mathrm{~S}$.

Passera L., Keller L. 1990. Loss of mating flight and shift in the pattern of carbohydrate storage in sexuals of ants (Hymenoptera, Formicidae) // J. Comp. Physiol. B. Vol.160. P.207-211.

Roma G.C., Bueno O.C., Camargo-Mathias M.I. 2010. Morphophysiological analysis of the insect fat body: a review // Micron. Vol.41. P.395-401.

Schwanwitsch B.N. 1949.[The course of general entomology]. Moscow-Leningrad: Sovetskaya nauka. 900 pp. [In Russian].

Yoder M.J., Mikó I., Seltmann K.C., Bertone M.A., Deans A.R. 2010. A gross anatomy ontology for Hymenoptera// PLoS ONE 5 (12): e15991. http://dx.doi.org/10.1371/journal.pone.0015991

Zakharov A.A. 2011. [The ants: a strategy of population concentration] // Zhurnal Obshchei Biologii. Vol.72. No.4. P.269-283 [in Russian, with an English summary].

Zakharov A.A. 2015. [Ants of the forest communities, its life and role in the forest] M.: KMK Scientific Press. 404 pp. [In Russian] 